ELORE (ISSN 1456-3010), vol. 19 - 1/2012.

Julkaisija: Suomen Kansantietouden Tutkijain Seura ry.

[http://www.elore.fi/arkisto/1_12/fingerroos_kirja.pdf]

KIRJA-ARVIO

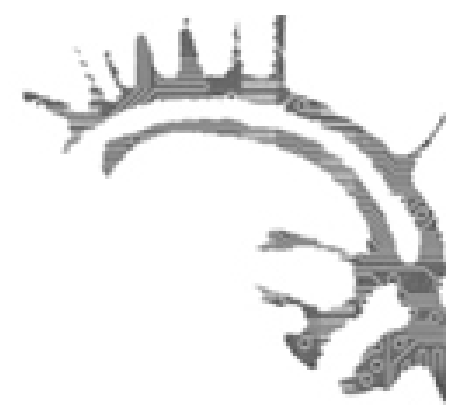

\title{
MAAHANMUUTON SUKUPOLVISTUMINEN HAASTAA KIELI- JA KOULUTUSPOLITIIKAN
}

MARTIKAINEN, TUOMAS \& HAIKKOLA, LOTTA (toim.) 2010: Maabanmuntto ja sukupolvet. Tietolipas 233. Helsinki: SKS. 299 sivua.

\section{Outi Fingerroos}

Maahanmuntto ja sukupolvet-artikkelikokoelma paneutuu Suomeen tulleiden maahanmuuttajaperheiden lapsiin eli maahanmuuttajien toiseen sukupolveen. Kirja on osa keskustelua maahanmunton sukupolvistumisesta eli siitä, että maahanmuuttajavanhempien ja heidän lastensa kokemukset eroavat toisistaan. Angloamerikkalaisessa tutkimuksessa sukupolvinäkökulma ajankohtaistui jo 1990-luvun puolivälissä, mutta suomalaiseen tutkimukseen toisen polven maahanmuuttajat tekevät vasta tuloaan. Mediassa ilmiö sen sijaan on kärjistynyt melko negatiivisiksi kannanotoiksi lähiömellakoista, koulujen ja asuntoalueiden eriarvoistumisesta, kunniaväkivallasta ja islamin radikalisoitumisesta.

Kirjan lähtökohtana on se, että kiinnostus toista maahanmuuttajasukupolvea kohtaan on Suomessakin virinnyt, mutta tutkimustulokset ovat vielä vähäisiä. Kirja koostuu neljästä luvusta, jotka ovat toimittajien mukaan myös keskeisiä toisen sukupolven kotoutumiseen vaikuttavia tekijöitä: perhe, koulutus, monikielisyys sekä identiteetti ja erilaisuus. Kokoelman johdannossa toimittajat Tuomas Martikainen ja Lotta Haikkola avaavat keskeisimmät sukupolviin ja maahanmuuttajuuteen liittyvät käsitteet sekä kirjoittavat lyhyesti kotimaisesta ja kansainvälisestä, lähinnä yhteiskuntatieteellisestä tutkimuksesta. Mukana on myös joukko tilastoja, jotka kertovat, keitä Suomeen on muuttanut eri aikoina. Artikkeleita kokoelmassa on yhteensä 13 ja niiden näkökulmat vievät moneen suuntaan. Mukana ovat muun muassa (soveltava) kielentutkimus, käyttäytymistieteet, koulutuksen tutkimus ja yhteiskuntatieteellinen tutkimus. 
Outi Fingerroos: Maahanmuuton sukupolvistuminen haastaa kieli- ja koulutuspolitiikan

\section{Perhe ja koulutus}

Kokoelman ensimmäisissä artikkeleissa Anne Alitolppa-Niitamo ja Marja Peltola paneutuvat perheen tematiikkaan yhteiskuntatieteellisestä näkökulmasta. AlitolppaNiitamon artikkeli on katsaus perhesuhteiden muutoksiin akkulturaatioprosessin aikana. Kansainvälisiä tutkimustuloksia esittelevän katsauksen tärkeä sanoma on se, että globalisaatiosta huolimatta perhemuodot ja kulttuurit pysyvät erilaisina, mikä usein synnyttää maahanmuuttajaperheisiin sukupolvien välisiä akkulturaatiokuiluja. Marja Peltolan artikkelissa akkulturaatioon liittyvät keskustelut konkretisoituvat, sillä hän esittelee maahanmuuttajaperheitä käsittelevän väitöskirjansa etnografisia tuloksia. Kiinnostavaa Peltolan tutkimuksessa on se, että maahanmuuttajanuorten akkulturaatio on Suomessa päämäärätietoista: he panostavat koulutukseen, haluavat itselleen kunnollisen ammatin ja tavoittelevat "kunnon kansalaisuutta". Se, miten Peltolan haastattelemille nuorille aikuisena käy, jää lähitulevaisuudessa nähtäväksi.

Nuorten maahanmuuttajien kouluttautumisen haaste on myös Marianne Teräksen, Johanna Lasosen ja Annalisa Sannion yhteisartikkelin teemana. Artikkelin fokuksessa ovat maahanmuuttajataustaisten lasten ja nuorten siirtymät koulutusasteelta toiselle ja lopulta työelämään. Artikkeli perustuu tilastoihin, lähinnä eurooppalaiseen tutkimuskirjallisuuteen ja PISA 2003 -tutkimustuloksiin, eikä se siksi anna kovinkaan syvällistä selitystä sille, miten juuri suomalaiset lapset ja nuoret selviävät erilaisista siirtymistä ja nivelvaiheista. Elina Kilven ja Sanna Markkasen koulutussosiologiset tekstit kuitenkin täydentävät edellisen artikkelin puutteita. He osoittavat, että Suomessa maahanmuuttajien toinen sukupolvi menestyy koulussa lähes yhtä hyvin kuin niin sanottu kantaväestö. Monet nuoret myös haluavat jatkaa peruskoulun jälkeen lukioon. Koulumenestykseen liittyvät ongelmat eivät Suomessa näyttäisi olevan niinkään etnisiä kuin yhteiskunnallisia. Huono-osaisuus on maahanmuuttajienkin keskuudessa kumuloituvaa ja ilmiön taustalla ovat vanhempien työllistymisongelmat.

\section{MONIKIELISYYS}

Maahanmuntto ja sukupolvet -artikkelikokoelman painavimmat puheenvuorot löytyvät "Monikielisyys"-osion artikkeleista. Suomen perustuslakiin on kirjattu kansalaisten oikeus omaan kieleen ja kulttuuriin sekä näiden kehittämiseen. Sirkku Latomaa ja Minna Suni paneutuvat toisen maahanmuuttajasukupolven kielellisiin kompetensseihin. He todentavat, että suomalainen koulutusjärjestelmä on merkittävän haasteen edessä, sillä toisen polven maahanmuuttajien kielellinen hybridinen repertoaari poikkeaa siitä, mitkä ovat käsityksemme kielitaidosta, äidinkielestä ja kirjallisuudesta. Suomalainen kielikoulutuspolitiikka ei vielä tunnista uusien suomalaisten kielirepertoaareja ja etenkin kuntatasolla vastuuta maahanmuuttajataustaisten oppijoista on helppo väistää.

Tatjana Rynkäsen ja Sari Pöyhösen artikkeli venäjänkielisistä nuorista täydentää mainiosti Latomaan ja Sunin tekstiä. Tutkimustulokset ovat siitä mielenkiintoisia, että suomi on kaikille ryhmille julkisen vuorovaikutuksen kieli. Venäjän kielen ylläpito ja 
kehittäminen sen sijaan jäävät pitkälti perheiden ja nuorten oman aktiivisuuden varaan. Kahden ja puolen vuoden ikäisenä Suomeen muuttaneen Maksimin esimerkki kuvaa hyvin sitä kielellistä hybridisaatiota, josta Latomaa ja Suni kirjoittivat edellä: Maksimille venäjän kieli oli yläkoulussa kaikkein vaikein aine, koska hän ei ollut lukenut sitä koskaan ennen ja kielen monimutkaisuus tuli hänelle täytenä yllätyksenä.

Kirjan kolmannen osion päättää Boglárka Strasserin artikkeli toisen polven unkarilaisten kieli-identiteetistä. Erityistä unkarilaisten kohdalla on se, että he ovat suomalaisten veljeskansaa. Unkaria puhuvat nuoret säästyvätkin monilta sellaisilta negatiivisilta stereotypioilta, joihin vaikkapa venäjä puhuva tai afrikkalaistaustainen väestö törmää Suomessa.

\section{IDENTITEETTI JA ERILAISUUS}

Kirjan päättää neljä identiteetin ja erilaisuuden teemoihin paneutuvaa artikkelia. Näissä kaikissa osoitetaan, että maahanmuuttajanuoret määrittelevät identiteettejään yhteiskunnallisessa tilanteessa, jota luonnehtii pysyvyyden sijaan muutos. Lotta Haikkola kirjoittaa helsinkiläisten maahanmuuttajanuorten identiteettikokemuksista. Hän osoittaa, että maahanmuuttajanuorten etninen identifioituminen tuottaa samanlaisia elämähistoriaan ja omiin juuriin sidoksissa olevia hybridejä kuin kielikin. Osa nuorista on kosmopoliitteja, jotka löytävät juurensa moniin maihin levittyvistä perheverkostoista ja omasta tulevaisuudestaan Suomessa tai muualla maailmassa. Saara Oksanen tarkastelee maahanmuuttajaidentiteettejä nuorten somalinaisten kokemana ja Antti Kivijärvi ja Veronika Honkasalo suhteessa aikuisuuteen, nuorisotyöhön ja rasismiin. Kirjan päättävässä artikkelissa Päivi Harinen ja Jussi Ronkainen paneutuvat monikulttuurisuuteen osana suomalaisten nuorten arkea. He nostavat nuorten elämästä esiin tärkeän teeman, kohtaamisen merkityksen ja välttämättömyyden: monikulttuurisilla nuorilla on halua ja kykyä ymmärtää muita ja he myös ymmärtävät kohtaamisten välttämättömyyden.

Identiteettiä ja erilaisuutta käsittelevän osan perään jäin kaipaamaan toimittajilta kokoavaa puheenvuoroa siitä, miten nuorten perheverkostot, koulutuspolut, kielivalinnat, identiteetit, rasismin kokemukset ja ryhmäsuhteet lopulta asettuvat keskenään dialogiin. Kokoelmassa oli paljon puhuttelevia tekstejä, mutta se, mitä annettavaa monitieteisellä ja -näkökulmaisella tutkimuksella on toisen polven maahanmuuttajille tai yhteiskunnalliselle keskustelulle maahanmunton sukupolvistumisesta, jää lopussa lausumatta. Tutkijoilla onkin edessään tärkeitä tehtäviä: julkaisemalla tutkimustuloksiaan ja osallistumalla aktiivisesti yhteiskunnalliseen keskusteluun he voivat edistää yksilöiden perusoikeuksien parempaa toteutumista. Kirjan toimittajia Tuomas Martikaista ja Lotta Haikkolaa haluan kuitenkin kiittää tarpeellisesta pelinavauksesta. Kuten he toteavat itsekin, toinen sukupolvi muuttaa lähitulevaisuudessa suomalaista maahanmuuttajiin liittyvää keskustelua ja suomalaista yhteiskuntaa.

\section{Dosentti Outi Fingerroos työskentelee etnologian yliopistotutkijana Jyväskylän yliopistossa.}

